\title{
Abundance and Symbiotic Rhizobia Colonizing Soybean (Glycine max) in Soils of Kakamega County, Western Kenya
}

\author{
Samuel Mulama $\mathbb{D}^{1},{ }^{1}$ Rose Onamu, ${ }^{2}$ Fredrick Odongo, ${ }^{1}$ and John Muoma ${ }^{1}$ \\ ${ }^{1}$ Department of Biological Sciences, School of Natural Sciences, Masinde Muliro University of Science and Technology, \\ P.O. Box 190-50100, Kakamega, Kenya \\ ${ }^{2}$ Department of Agricultural and Land Use Management, School of Agriculture and Veterinary Technology, \\ Masinde Muliro University of Science and Technology, P.O. Box 190-50100, Kakamega, Kenya \\ Correspondence should be addressed to Samuel Mulama; mulamasamuel@yahoo.com
}

Received 24 February 2021; Revised 15 May 2021; Accepted 13 July 2021; Published 12 August 2021

Academic Editor: Vera Popovic

Copyright (C) 2021 Samuel Mulama et al. This is an open access article distributed under the Creative Commons Attribution License, which permits unrestricted use, distribution, and reproduction in any medium, provided the original work is properly cited.

\begin{abstract}
Identification of effective indigenous rhizobia strain nodulating soybean (Glycine max) was conducted in Kakamega County, Western Kenya. This study was carried out to establish the abundance and symbiotic efficiency of native rhizobia strains in soil samples collected from 12 sites in four agroecological zones within the region. The MPN enumeration technique was used to estimate the indigenous rhizobia numbers and showed that $54 \%$ of the sampled sites had high abundance. Rhizobia number in the soil collected from the six regions varied from $2.5 \times 10^{2}$ to $3.12 \times 10^{3}$ cells.g ${ }^{-}$soil. Thirty isolates from the soil collected in the four regions were tested for efficiency using soybean as the trap plant in Leonard jars containing sterilized vermiculite irrigated with nitrogen-free media. Determination of the relationship between rhizobial abundance and symbiotic efficiency with respect to the soil chemical conditions was performed using ANOVA, and the means were compared using Tukey's honest significant difference test. Inoculation with bacterial isolates significantly $(P<0.05)$ increased the nodule number and shoot dry weight, while weight of the seeds showed variations across the groups. The soil pH across the 4 regions ranged between 5.41 and 6.52.
\end{abstract}

\section{Introduction}

Soybean (Glycine max) is a grain legume providing dietary protein to millions of people, especially in sub-Saharan countries [1-3]. The crop is grown by both commercial and subsistence farmers. Soybean has a high protein content of about 40\%, 18\% lipid, and 6.3\% carbohydrate [4]. South Africa is the leading producer of soybean, followed by Nigeria, Zambia, and Uganda among other countries in subSaharan Africa [5]. Expansion and increase in soybean production in SSA since early 1970s to 2018 has rapidly grown popular [6]. Root nodulating bacteria strains are important property in soybean production since the strains must compete with each other in the rhizosphere for better yield production [7-9]. Rhizobia are bacteria that establish a symbiotic relationship with the host plant which results in the formation of plant root nodules through colonization and fixation of atmospheric nitrogen $[10,11]$. These bacteria can be divided into two broad groups: free-living rhizobacteria which live outside the plant and symbiotic endophytic bacteria which live inside the plant cell [12]. In this case, both the free-living and endophytic bacteria are crucial in nutrient metabolism [13].

For soybean, like many other grain legumes, nodulation in the field is induced by different rhizobium strains which work in association that produce $50 \%$ of 175 million tons of total biological nitrogen fixation (BNF) [14].

Kenya, among other sub-Saharan countries, experiences the failure of inoculation to elicit response in legumes. This calls for the need to practice sustainable farming through the utilization of natural micro-organisms to boost the soil fertility [13]. However, inoculants obtained from a reliable source should contain only rhizobial strains that are highly effective nitrogen fixers $[15,16]$. Bacterial strains such as Bacillus, Pseudomonas, Azospirillum, Azotobacter, and Enterobacter have been used in the past as biofertilizer [6]. 
Glycine max is nodulated by many species of rhizobia, and in this case, it is considered as a promiscuous host [17]. These microbial species are spatial distributed based on the niche selection and agroecological zones which vary considerably. There is need for inoculation of legumes where there is deficiency of rhizobia. This study aimed at the determination of the abundance and symbiotic efficiency of rhizobial strains colonizing Glycine max in soils of Kakamega County, Western Kenya.

\section{Materials and Methods}

2.1. Soil Sampling Sites. Soil sampling was carried out where farmers had grown soybeans frequently. Sampling was carried out in four regions across Kakamega County. The areas were mapped, and attitude and co-ordinates were taken by using the GPS machine, as indicated in Figure 1: Kakamega South (N00.2839 ${ }^{\circ}$ E034.72255 ${ }^{\circ}$, Kakamega Central (N00.28751, E034.76546 ${ }^{\circ} \quad\left(\mathrm{N} 00.28752^{\circ}, \quad\right.$ E034.76547, N00.29178, E034.73947), Kakamega East (N00.29178, E034.73947, N00.21563, E034.76547, N00.21365, E034.77162), and Kakamega North (N00.424070, E034.887390, N00.429220, E034.900790, N00.426200, E034.91863). Greenhouse and laboratory study were conducted at Masinde Muliro University of science and Technology (MMUST).

\subsection{Abundance Determination of Native Rhizobia in the Soil}

2.2.1. Soil Sampling and Analysis. A 20 soil core was randomly collected from each farm at a depth of $20 \mathrm{~cm}$ and thoroughly mixed into a composite sample to obtain a homogenous sample. The surface debris was cleared using a sterile shovel, and 15 grams of the soil was taken at an interval of 10 meters in a $Z$ pattern within the field of interest. The collected soil was mixed into homogenous composite soil packed into khaki bags transported in the ice box to the laboratory.

The soil was divided into two, one part for abundance and the other part for chemical and physical analysis. The soil sample for physical and chemical analysis was air dried in the laboratory before being taken for analysis at the University of Nairobi, College of Agriculture and Veterinary Sciences, Department of Land Resource Management and Agricultural Technology. The second set of soil samples was prepared in 10-fold dilution series. From every dilution, one milliliter was inoculated onto a three-day-old seedling grown in vermiculite in the greenhouse. Dilutions ranged from $10^{-1}$ to $10^{-6}$ with 3 soil replication samples from the collection sites. Diluted soil inoculation was performed on the seedlings in the jars within the greenhouse. The sample size comprised of one hundred and eight (108) Leonard jars put in brown khaki bags arranged in a completely randomized block design (CRBD) on the greenhouse shelves.

2.2.2. Seed Treatment. Pure soybean seeds of gazelle variety obtained from KALRO-Njoro were used as the trapping host. The seeds were pretested for germination to ascertain synchronization which resulted to $99 \%$ germination rate.
Seeds were then immersed in 95\% ethanol to remove waxy substances from the cortex and to reduce the surface tension followed by surface sterilization with $3 \%$ sodium hypochlorite for 5 minutes. They were then rinsed in five series of distilled water and then immersed in $0.2 \%$ acidified mercuric chloride for further surface sterilization for 5 minutes. Seeds were then finally rinsed in five changes of sterile distilled water, placed in Petri dishes containing moist cotton wool, wrapped with parafilm, and put in a germination chamber for pregermination. After 3 days, two germinated seeds were transplanted in Leonard jars containing sterilized vermiculite of $\mathrm{pH} 6.8$.

\subsubsection{Preparation of a Nitrogen-Free Nutrient Solution.} Irrigation of seedlings was performed with a sterile nitrogenfree plant nutrient solution comprising macroelements, microelements, iron salts, and vitamins contained in $\mathrm{g} / \mathrm{l}$, and the $\mathrm{pH}$ solution was adjusted to 6.8 using $1 \mathrm{M} \mathrm{NaOH}$ or $1 \mathrm{M}$ HCL. The stock solutions used consisted of $0.1 \mathrm{CaCl}_{2}$, $0.12 \mathrm{MgSO}_{4} .7 \mathrm{H}_{2} \mathrm{O}, \quad 0.1 \mathrm{KH}_{2} \mathrm{PO}_{4}, \quad 0.15 \mathrm{Na}_{2} \mathrm{HPO}_{4} .2 \mathrm{H}_{2} \mathrm{O}$, and 0.005 ferric citrate. $1.0 \mathrm{~mL}$ trace elements consisted of 2.86 $\mathrm{H}_{3} \mathrm{BO}_{3}, \quad 2.03 \mathrm{MnSO}_{4} .7 \mathrm{H}_{2} \mathrm{O}, \quad 0.22 \quad \mathrm{ZnSO}_{4} .7 \mathrm{H}_{2} \mathrm{O}$, $0.08 \mathrm{CuSO}_{4} \cdot 5 \mathrm{H}_{2} \mathrm{O}$, and $0.14 \mathrm{NaMoO}_{2} \cdot 2 \mathrm{H}_{2} \mathrm{O}$ in $\mathrm{g} / \mathrm{l}$.

2.2.4. Nodule Sampling, Storage, and Bacterial Isolation. Plants were uprooted after six weeks, each examined, and scored according to the presence or absence of nodules. The presence of single or more nodules was considered as positive, while the absence of nodules was taken as negative. Nodules on each plant were carefully removed from the roots, put in test tubes containing silica gel and cotton, capped properly, and stored under $-4^{\circ} \mathrm{C}$ for further use. Stored nodules were immersed in sterile distilled water in order to imbibe and restore their shape and surface sterilized for 3-5 minutes in 3\% $\mathrm{NaOCl}$ and 70\% ethanol, respectively. Nodules were then rinsed in a series of distilled water and crushed on sterilized Petri dishes using a blunt pathogenfree forceps, and a loop of crushed suspension was streaked on Petri dishes containing media. The media used for culturing putative rhizobia contained $5 \mathrm{~g} / \mathrm{l}$ of peptone from casein, $3 \mathrm{~g} / \mathrm{l}$ of yeast extract, $1.5 \mathrm{~g} / \mathrm{l}$ agar, and $1 \mathrm{ml}$ calcium chloride $0.7 \mathrm{M}$ of $10 \mathrm{ml} / \mathrm{l}(5 \mathrm{~g} / \mathrm{l})$ and supplemented with nalidixic acid and then incubated in the dark at $28^{\circ} \mathrm{C}$. After 3 days of observable growth, restreaking on new media was carried out in order to get specific colonies. Plating was performed on lysogenic broth (LB) and peptone yeast (PY); the former was used as a negative control. After 2 days, specific colonies from the cultures were scooped using a sterile inoculation loop and recultured for further use.

2.3. Authentication of the Isolates and Symbiotic Efficiency. Five-day soybean plantlets growing in vermiculite and irrigated with a nitrogen-free nutrient solution in Leonard jars were inoculated with $1 \mathrm{ml}$ of pure colonies of bacterial culture. Watering with nitrogen-free media was performed on the test plants. Experiment comprised the soybean gazelle variety planted in vermiculite without inoculation which 


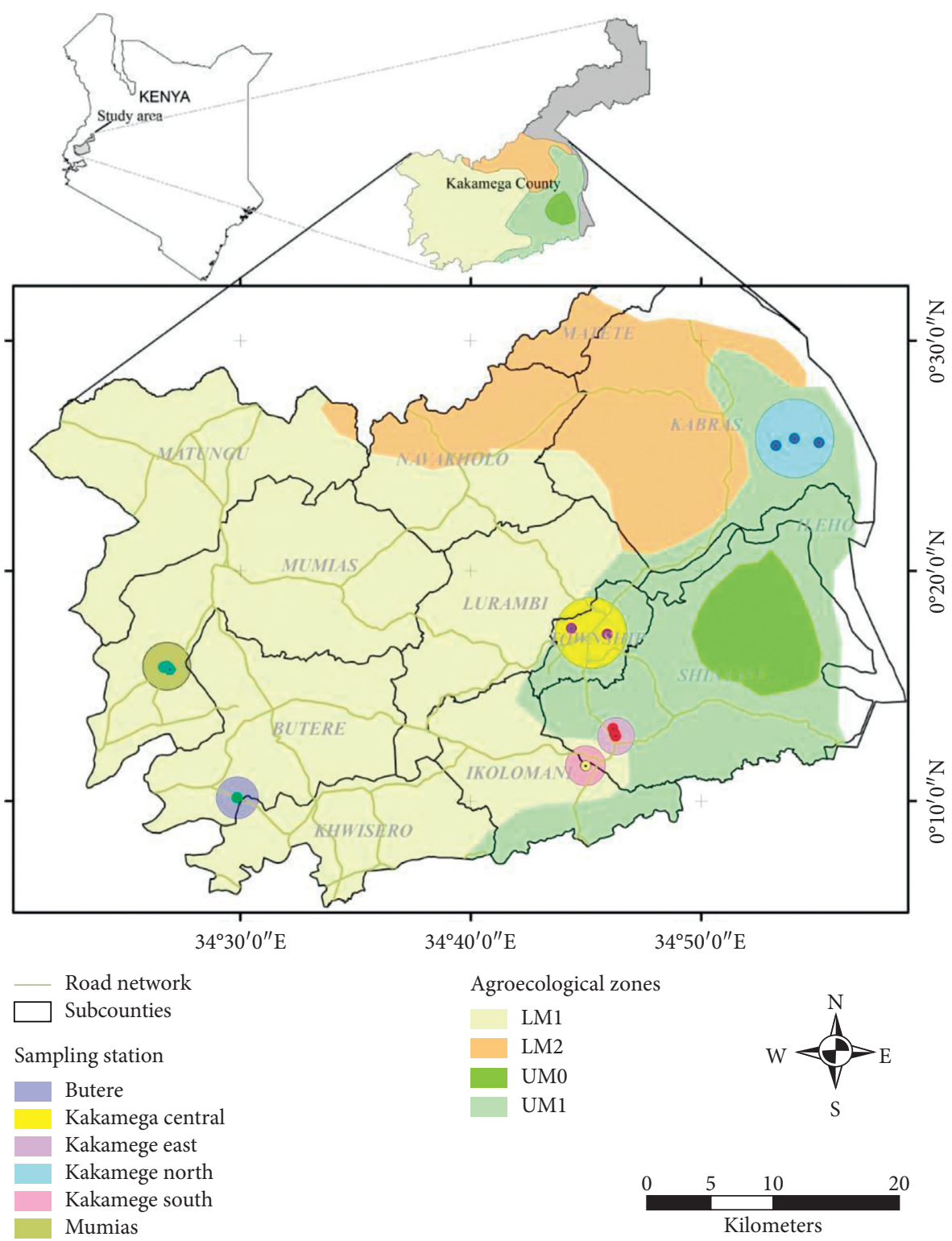

FIgURe 1: A map showing the study area.

served as the negative control and two treatments applied with $\mathrm{KNO}_{3}$ fertilizer at a rate of $70 \mu \mathrm{g}-1$ for the positive control. Alternatively, $0.025 \mathrm{~g} / \mathrm{l}$ of Congo red was added to normal YEM and cultured in the dark incubation chamber at $28^{\circ} \mathrm{C}$ for two days.

2.4. Data Collection. Data collection for determination of efficiency and abundance was performed in two phases. The first phase comprised the number of nodules per plant and average weight of nodules and dry mass of the shoot. The second phase encompassed of the number of pods per plant, weight of the pods, number of seeds per pod, and the average weight of the seeds. Thirty (30) plants were randomly picked and carefully uprooted without disturbing the root system to obtain the nodules. Nodules were put in a khaki envelop, labeled, and dried in an oven at $60^{\circ} \mathrm{C}$ for 48 hours to determine nodule dry weight. The shoot was detached from the root system using a scalpel and oven dried at $60^{\circ} \mathrm{C}$ for 3 days to determine shoot dry weight. In the second phase, thirty isolates were obtained. These isolates were inoculated on soybean planted in vermiculite in the Leonard jars and watered with nitrogen-free growth media. At maturity, plants were assessed for the pod number and average pods. Pods were handpicked, packed in khaki bags per plant, and oven dried for 72 hours at $60^{\circ} \mathrm{C}$ to determine their weight. The number of seeds was counted from each pod, and their average based on each pod and yield was determined.

2.5. Statistical Analysis. Abundance was subjected to MPNES. Results obtained as MPNs were analysed using ANOVA. Symbiotic efficiency and the abundance were subjected to python. All figures were drawn by matplotilib version 3.1.3 in python 3.7.6. ANOVA and Tukey's post hoc were performed with stats model version 0.11.0 in python 
TABLE 1: Soil properties collected from four regions and the most probable numbers of bacteria.

\begin{tabular}{|c|c|c|c|c|c|c|c|c|c|c|}
\hline \multicolumn{11}{|c|}{ Soil characteristics } \\
\hline \multicolumn{5}{|c|}{ Ppm } & \multicolumn{4}{|c|}{$\mathrm{cmol} / \mathrm{kg}$} & ppm & \multirow[t]{2}{*}{ MPN } \\
\hline Region & $\mathrm{pH}$ & $\% \mathrm{~N}$ & $\%$ O. carbon & $\mathrm{P}$ & $\mathrm{K}$ & $\mathrm{Ca}$ & $\mathrm{Mg}$ & $\mathrm{Al}$ & $\mathrm{Zn}$ & \\
\hline Kakamega Central (A) & 5.41 & 0.55 & 1.31 & 25 & 0.7 & 2.75 & 1.10 & 1.2 & 6.4 & $2.9 \times 10^{3}$ \\
\hline Kakamega Central (B) & 5.50 & 0.46 & 0.90 & 27.5 & 0.25 & 1.50 & 0.52 & 1.1 & 5.5 & $2.68 \times 10^{3}$ \\
\hline Kakamega Central (C) & 5.82 & 0.46 & 1.95 & 22.5 & 0.95 & 4.25 & 1.65 & 0.9 & 4.4 & $3.09 \times 10^{3}$ \\
\hline Kakamega East (A) & 5.43 & 0.45 & 2.30 & 20 & 0.6 & 2 & 1.64 & 0.9 & 5.74 & $0.74 \times 10^{2}$ \\
\hline Kakamega East (B) & 5.62 & 0.32 & 1.62 & 12.5 & 0.6 & 2.5 & 0.95 & 1.1 & 4.45 & $0.97 \times 10^{2}$ \\
\hline Kakamega East (C) & 5.54 & 0.34 & 1.54 & 35 & 0.7 & 3 & 1.02 & 0.85 & 5.85 & $1.02 \times 10^{2}$ \\
\hline Kakamega South (A) & 5.60 & 0.39 & 1.71 & 20 & 1 & 4 & 1.56 & 0.75 & 6.05 & $9.19 \times 10^{2}$ \\
\hline Kakamega South (B) & 6.52 & 0.35 & 2.08 & 55 & 2.4 & 9.5 & 3.25 & 0.65 & 6.52 & $9.27 \times 10^{2}$ \\
\hline Kakamega South (C) & 6.12 & 0.31 & 1.69 & 27.5 & 0.95 & 4.0 & 1.56 & 0.55 & 4.44 & $9.11 \times 10^{2}$ \\
\hline Kakamega North (A) & 5.81 & 0.42 & 2.65 & 30 & 1.1 & 5 & 1.90 & 0.75 & 6.25 & $2.09 \times 10^{3}$ \\
\hline Kakamega North (B) & 5.83 & 0.39 & 1.29 & 25 & 0.95 & 3.75 & 1.24 & 0.95 & 5.16 & $3.12 \times 10^{3}$ \\
\hline Kakamega North (C) & 5.75 & 0.48 & 1.17 & 20 & 0.25 & 1.50 & 0.51 & 1.4 & 7.56 & $2.07 \times 10^{3}$ \\
\hline
\end{tabular}

3.7.6. Findings of the study were reported significant at $P<0.05$.

\section{Results}

3.1. Soil Characteristics. Chemical analysis of collected soil showed great variations in terms of their soil $\mathrm{pH}$, phosphorus, organic carbon, nitrogen, potassium, and aluminium (Table 1). Soil collected ranged from sandy loam to sandy clay. Kakamega East had a $\mathrm{pH}$ of 5.43 with a slightly high aluminium content of $1.1 \mathrm{cmol} / \mathrm{kg}$ which was manifested in low nodulation among the six regions. Kakamega South had the highest soil $\mathrm{pH}$ of 6.52 and the organic carbon of $2.08 \%$. Variation of $\mathrm{pH}$ could be due to mineralization levels.

3.2. Authentication. All the thirty isolates significantly increased the number of nodules when they were inoculated on the 4-day soybean seedlings in the Leonard jars (Figure 2). In comparison, uninoculated plants had low nodule number. Verification of bacteria performed on YEM had small colorless colonies after incubation for two days under dark at $28^{\circ} \mathrm{C}$. Colorless colonies were a sign of the presence of rhizobia (Figure 3).

3.3. Abundance, Plant Growth, and Symbiotic Performance. Analysis of data on nodule number, nodule dry weight, shoot dry weight, number of pods per plant, and seed dry weight using one-way ANOVA revealed the correlation between inoculation of the plant with rhizobia and the plant growth in terms of symbiotic performance (Table 2). Kakamega North and Kakamega Central showed high population of bacteria per gram of soil and, therefore, demonstrated high shoot biomass which revealed high symbiotic performance as compared to Kakamega East and Kakamega South which had low nodule mass per plant. Positive samples were indicated by the presence of nodules per plant, while plants with no nodules had negative score (Table 3). Kakamega East, for instance, lies at a low medium zone had the lowest positive nodule number and shoot dry weight, and population of soybean rhizobia was found at

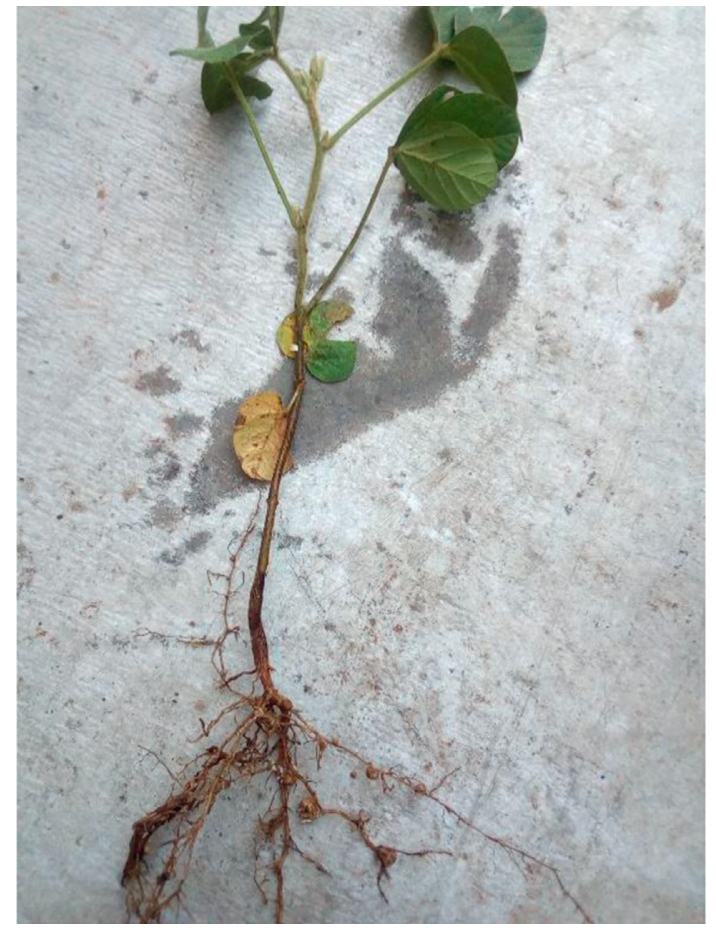

Figure 2: Uprooted plant with nodules.

$0.74 \times 10^{2}$ cells.g ${ }^{-}$soil. Isolates significantly increased plant performance in terms of yield, nodule number, and biomass (Figure 4). Kakamega Central had the highest bacteria population per gram of soil on enumeration (Figure 5).

\section{Discussion}

Root nodulating rhizobia counts varied from one genus to the other in their specificity and inoculation with rhizobia in this study have supported this view. Inappropriate inoculation where there is no perfect match will result to ineffective nodule or no nodule formation, and therefore, no nitrogen fixation will take place [15]. This study supports the findings [18] that host specificity depends on particular rhizobia. It was evident that large rhizobia counts occurred 


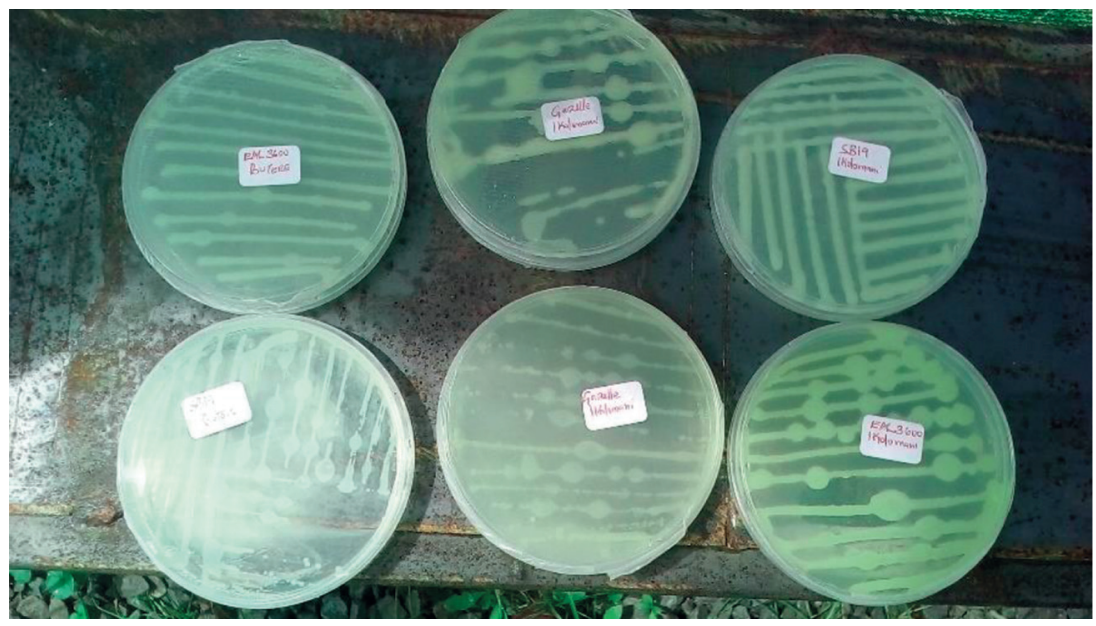

Figure 3: Plates showing rhizobia colonies.

TABLe 2: Mean numbers of nodules, NDW, SDW, pods, pod weight, number of seeds, and weight of seeds.

\begin{tabular}{lccccccc}
\hline Sites & No. of nodules & NDW & SDW & Pod number & Pod weight & Number of seeds & Weight of seeds \\
\hline South & 3 & 0.18 & 6.06 & 4 & 1.56 & 11 & 0.93 \\
East & 2 & 0.01 & 5.18 & 5 & 1.86 & 1.73 & 9 \\
Central & 3 & 0.03 & 4.62 & 2 & 2.34 & 1.01 & 1.50 \\
North & 4 & 0.16 & 4.00 & 7 & & 1.51 \\
\hline
\end{tabular}

NDW- nodule dry weight; SDW- shoot dry weight.

TABLE 3: Isolation of rhizobia from the root nodule of soybean.

\begin{tabular}{lcccc}
\hline Sr. no. & Region & No. of samples & Positive $(+)$ & Negative $(-)$ \\
\hline 1 & Kakamega South & 18 & 8 & 10 \\
2 & Kakamega East & 18 & 10 & 13 \\
3 & Kakamega Central & 18 & 10 & 8 \\
4 & Kakamega North & 18 & $\mathbf{3 3}$ & 8 \\
\hline & Total & $\mathbf{7 2}$ & 39 \\
\hline
\end{tabular}

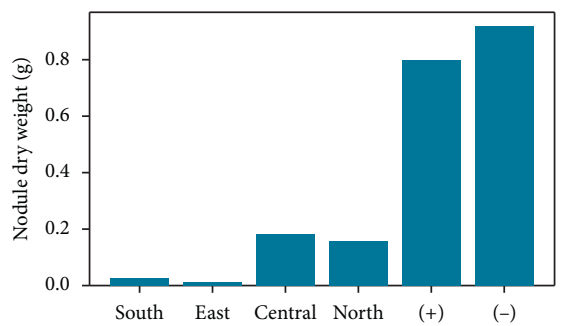

(a)

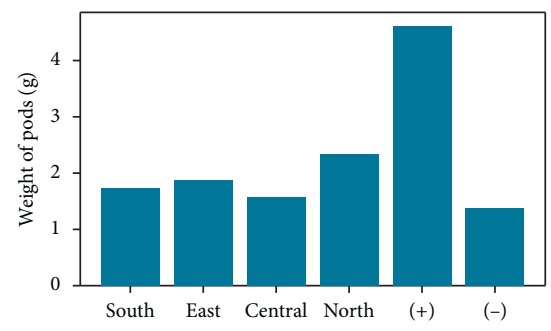

(d)

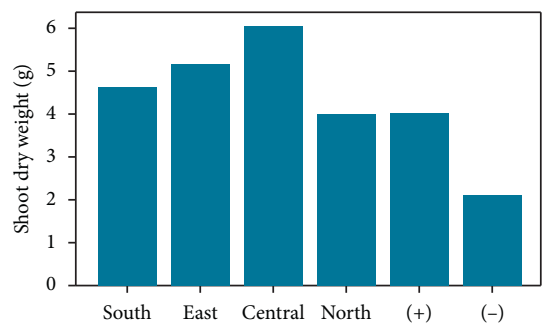

(b)

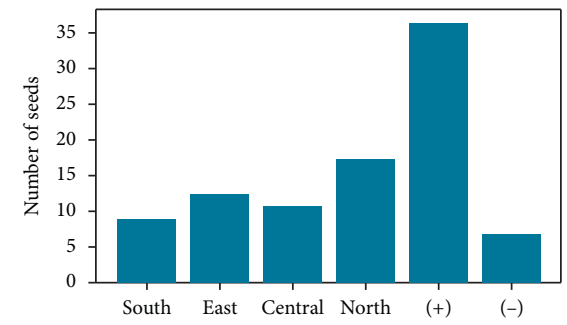

(e)

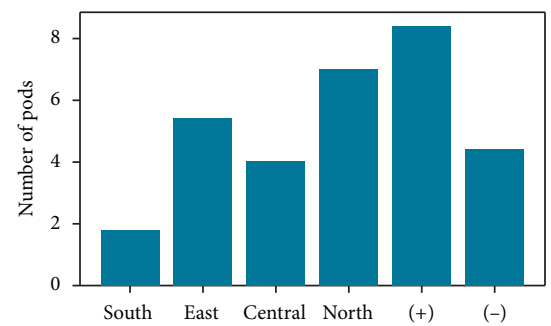

(c)

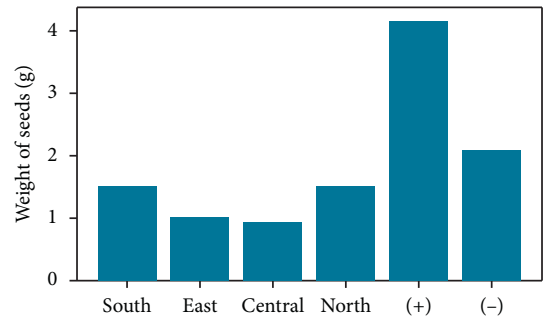

(f)

FIGURE 4: Effects of rhizobia on shoot dry weight, number of pods, pod weight, seed number per plant, and weight of seeds. 


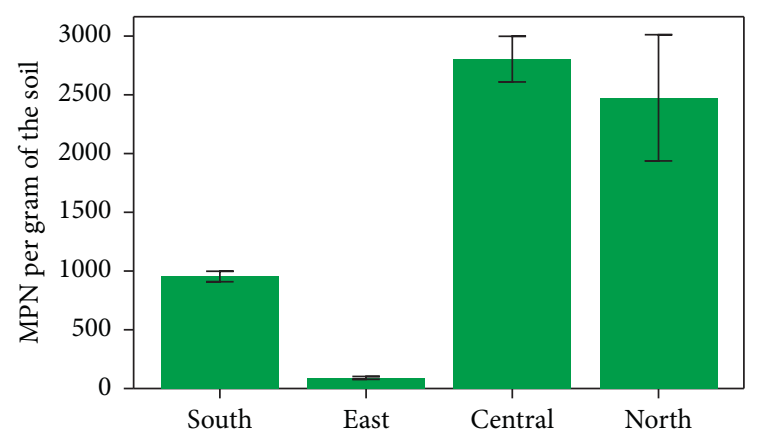

FIGURE 5: Enumerated most probable numbers of bacteria population from four regions.

in soils from Kakamega North $\left(3.12 \times 10^{3}\right.$ cell/g soil $)$. In addition, both Kakamega North and Kakamega Central had the highest nodulation of 10 nodules per plant. Soils that were found to have the highest bacterial population had increased the nodule number and nodule dry matter. The higher the abundance of rhizobia, the higher the symbiotic efficiency and the higher the SDW and grain weight $[13,19]$. However, some soil samples failed to nodulate, especially soil samples from Kakamega East which gave negative results and very low symbiotic performance. The MPN technique is based upon the patterns of positive or negative nodulation response of the plant in experiment which is inoculated based on dilution series [20].

\section{Conclusions}

This study indicates that Kakamega North and Kakamega Central had high population of bacteria per gram of soil and, therefore, high shoot biomass, high number of seed pods and plant dry mass, and increased seed yield. The detection of low bacteria population in Kakamega South and Kakamega East in soils was equally associated with relatively lower biomass and decreased seed yield. It can be concluded that the higher the abundance of root nodulating rhizobia within the soil, the higher the productivity of the host plant. This study has also shown that there is a general variation in the abundance of rhizobia population within the different study sites, hence encouraging farmers to use inoculants. Inoculation can increase the rhizobia population and, therefore, increase the bioavailable nitrogen for farmers.

\section{Data Availability}

Data are available from the corresponding author upon request.

\section{Conflicts of Interest}

The authors declare no conflicts of interest.

\section{Acknowledgments}

The authors would like to thank Masinde Muliro University of Science and Technology (MMUST) for provision of university research grant of Ksh.100,000. They extend special thanks to Mr. Peter Nyongesa, Department of Biological Sciences, Masinde Muliro University of Science and Technology, and Mr. Clabe Wekesa, Matthias Schleiden Institute of Plant Physiology, Friedrich-Schiller-University Jena, for their advisory and laboratory support.

\section{References}

[1] P. A. Ndakidemi, F. D. Dakora, E. M. Nkonya, D. Ringo, and H. Mansoor, "Yield and economic benefits of common bean (Phaseolus vulgaris) and soybean (Glycine max) inoculation in northern Tanzania," Australian Journal of Experimental Agriculture, vol. 46, no. 4, pp. 571-577, 2006.

[2] C. H. Foyer, K. H. M. Siddique, A. P. K. Tai et al., "Modelling predicts that soybean is poised to dominate crop production across Africa," Plant, Cell \& Environment, vol. 42, no. 1, pp. 373-385, 2019.

[3] I. De Jager, K. J. Borgonjen-Van Den Berg, K. E. Giller, and I. D. Brouwer, "Current and potential role of grain legumes on protein and micronutrient adequacy of the diet of rural Ghanaian infants and young children: using linear programming," Nutrition Journal, vol. 18, no. 1, p. 12, 2019.

[4] S. Refstie, S. Sahlström, E. Bråthen, G. Baeverfjord, and P. Krogedal, "Lactic acid fermentation eliminates indigestible carbohydrates and antinutritional factors in soybean meal for Atlantic salmon (Salmo salar)," Aquaculture, vol. 246, no. 1-4, pp. 331-345, 2005.

[5] D. M. Khojely, S. E. Ibrahim, E. Sapey, and T. Han, "History, current status, and prospects of soybean production and research in sub-Saharan Africa," The Crop Journal, vol. 6, no. 3, pp. 226-235, 2018.

[6] K. V. B. R. Tilak, N. Ranganayaki, and C. Manoharachari, "Synergistic effects of plant-growth promoting rhizobacteria and Rhizobium on nodulation and nitrogen fixation by pigeonpea (Cajanus cajan)," European Journal of Soil Science, vol. 57, no. 1, pp. 67-71, 2006.

[7] F. Mabood, X. Zhou, and D. L. Smith, "Microbial signaling and plant growth promotion," Canadian Journal of Plant Science, vol. 94, no. 6, pp. 1051-1063, 2014.

[8] S. Youseif, F. Abd El-Megeed, and S. Saleh, "Improvement of faba bean yield using Rhizobium/Agrobacterium inoculant in low-fertility sandy soil," Agronomy, vol. 7, no. 1, p. 2, 2017.

[9] Y. Mora, R. Díaz, C. Vargas-Lagunas et al., "Nitrogen-fixing rhizobial strains isolated from common bean seeds: phylogeny, physiology, and genome analysis," Applied and Environmental Microbiology, vol. 80, no. 18, pp. 5644-5654, 2014.

[10] T. Suzaki, E. Yoro, and M. Kawaguchi, "Leguminous plants: inventors of root nodules to accommodate symbiotic bacteria," International Review of Cell and Molecular Biology, vol. 316, pp. 111-158, 2015.

[11] R. Hayat, S. Ali, U. Amara, R. Khalid, and I. Ahmed, "Soil beneficial bacteria and their role in plant growth promotion: a review," Annals of Microbiology, vol. 60, no. 4, pp. 579-598, 2010.

[12] G. Brader, S. Compant, B. Mitter, F. Trognitz, and A. Sessitsch, "Metabolic potential of endophytic bacteria," Current Opinion in Biotechnology, vol. 27, pp. 30-37, 2014.

[13] H. H. Zahran, "Rhizobium-legume symbiosis and nitrogen fixation under severe conditions and in an arid climate," Microbiology and Molecular Biology Reviews, vol. 63, no. 4, pp. 968-989, 1999.

[14] E. D. S. Mendonça, P. C. D. Lima, G. P. Guimarães, W. D. M. Moura, and F. V. Andrade, "Biological nitrogen 
fixation by legumes and $\mathrm{N}$ uptake by coffee plants," Revista Brasileira de Ciência do Solo, vol. 41, 2017.

[15] K. Musiyiwa, S. Mpepereki, and K. E. Giller, "Symbiotic effectiveness and host ranges of indigenous rhizobia nodulating promiscuous soyabean varieties in Zimbabwean soils," Soil Biology and Biochemistry, vol. 37, no. 6, pp. 1169-1176, 2005.

[16] P. Kasasa, S. Mpepereki, and K. E. Giller, "Nodulation and yield of promiscuous soybean (Glycine Max (L.) Merr) varieties under field conditions," Soil Fertility Research for Maize-based Farming Systems in Malawi and Zimbabwe, CIMMYT, Harare, Zimbabwe, 1998.

[17] N. Boonkerd and P. Singleton, Production of Rhizobium Biofertilizer. Biotechnology of Biofertilizers, pp. 122-128, Narosa Publishing House, New Delhi, India, 2002.

[18] A. G. Khan, "Role of soil microbes in the rhizospheres of plants growing on trace metal contaminated soils in phytoremediation," Journal of Trace Elements in Medicine and Biology, vol. 18, no. 4, pp. 355-364, 2005.

[19] F. Kawaka, M. Dida, P. Opala et al., "Effect of nitrogen sources on the yield of common bean (Phaseolus vulgaris) in western Kenya," Journal of Plant Nutrition, vol. 41, no. 13, pp. 1652-1661, 2018.

[20] C. S. Wekesa, D. Okun, K. Juma et al., "Abundance and symbiotic potential of common bean (Phaseolus vulgaris) nodule associated bacteria in western Kenya soil," MAYFEB Journal of Agricultural Science, vol. 1, pp. 1-9, 2016. 